\title{
EFFECT OF LEADERSHIP STYLE ON SERVICE QUALITY AND JOB SATISFACTION AMONG HOSPITAL NURSES: A SYSTEMATIC REVIEW
}

\author{
Puspita Khairunnisa1), Mardiati Nadjib²) \\ ${ }^{1)}$ Masters Program in Public Health, Faculty of Public Health, Universitas Indonesia \\ ${ }^{2)}$ Department of Policy and Health Administration, Faculty of Public Health, Universitas Indonesia
}

\begin{abstract}
Background: Effective leadership of healthcare professionals is critical for strengthening quality and integration of care. There are numerous studies recognizing leadership style as a key element for quality of healthcare. Effective leadership is among the most critical components that affects successful outcomes. This study aimed to review systematically the effect of leadership style on service quality and job satisfaction among hospital nurses.

Subjects and Method: A systematic review was conducted by searching published articles from 2010 to 2019, from database including EBSCHO, PubMed, and Science Direct. The keywords were "leadership style", "job satisfaction", "quality care", "nurse", and "hospital". The inclusion criteria were articles published in the last 10 years, English, full text, open access journal, and research locations at hospitals. From screening of titles and abstracts, 15 articles were included in this review.

Results: Leadership style influenced job satisfaction $(r=0.16$ to $r=0.71)$. The transformational leadership style better than the transactional leadership style. Transformational leadership style increased $28 \%$ the quality of nurse services and patien satisfaction.

Conclusion: Strategy and transformational leadership style are effective to increase job satisfaction among nurses in improving the quality of service to patients.
\end{abstract}

Keywords: transformational, leadership, job satisfaction, quality of service, patients

\section{Correspondence:}

Puspita Khairunnisa. Masters Program in Public Health, Faculty of Public Health, Universitas Indonesia, Depok, West Java. Email: drg.puspita1985@gmail.com. Mobile: 081219450054.

\section{BACKGROUND}

Hospital is a health service institution that conducts complete individual health services that provide inpatient, outpatient and emergency services. Hospitals must have permanent staff including medical and medical support staff, nursing staff, pharmacy staff, hospital management staff, and non-health personnel (RI Law No.44 of 2009).

Nurses are the largest group of employees in hospitals. The percentage of nurses in Indonesia in 2016 was the biggest compared to other health workers, namely $29.66 \%$ (Ministry of Health, 2017). Nurses have a sufficient position to determine the high and low quality of health services in hospitals, because they are the ones who make direct contact every day and have the most time in interacting with patients (Setyawati, 2010).

Nurse's job satisfaction is a very important element and influences the quality of services in hospitals. According to Gibson \& Donnelly (2002) job satisfaction is a pleasant feeling condition that is produced by employees all the time in terms of understanding their work. The impact caused by dissatisfaction can be seen in the slowness of employees at work, high absenteeism, negligence, low achievement, low product quality and employee discipline problems (David and Fred, 2011). This shows that job satisfaction is an important aspect for nurses and organizations, especially because it is able to create a positive environment within the organization. 
The results of study done by Ramoo et al. (2014) in Malaysia showed that there was a significant relationship between job satisfaction and the desire of nurses to leave their jobs, where $40 \%$ of nurses left work due to dissatisfaction. Research in China conducted by Liu et al. (2012) showed that 54\% of nurses were dissatisfied with their work. Raeda et al. (2012) in Saudi Arabia show that nurse job satisfaction is low by $32 \%$. From this data, it shows that there are still many nurses abroad who are not satisfied with their work.

In addition, various studies have also been carried out in Indonesia, Research by Ningtyas (2002) in Wuryanto (2010) found that job satisfaction of implementing nurses with poor categories in the Government Hospital was $55.8 \%$. The results of study conducted by Noras (2010) entitled Comparison of Nurse's Job Satisfaction Level and Patient's Satisfaction Level indicate that the level of job satisfaction of implementing nurses is categorized low (22.5\%). This shows that there are still many nurses in Indonesia who are not satisfied with their job.

According to Bowles \& Bowles (2000) one of the causes of job satisfaction from nurses is influenced by leadership style factors that are applied in the workplace. Leadership style is proven to be very effective in influencing nurse job satisfaction. Through a leadership style a leader can treat subordinates or implementing nurses to work with heart and be more motivated so that nurses feel more satisfied at work.

The style of leadership of health professionals is very important to strengthen the quality and integration of care. Leadership has been defined as the relationship between individuals who lead and those who take the choice to follow, while it refers to the behavior of directing and coordinating the activities of a team or group of people towards the same goal (Al-Sawai, 2013).
In the full range theory model of leadership, there are three leadership styles namely transformational, transactional and laissez faire leadership. Effective leadership is the most important component that leads organizations to effective results (Wong, CA; Cummings, 2007). Effective leadership styles such as transformational and transactional leadership styles have a significant positive relationship with the level of patient satisfaction (Lang et al, 2004).

In addition, several studies have emphasized the importance of leadership style for the quality of health services in hospitals (Sfantou et al., 2017). The purpose of this study is to identify and conclude the influence of leadership style on job satisfaction and service quality in nurses in hospitals.

\section{SUBJECTS AND METHOD}

\section{Study Design}

This study is a systematic review through a journal review of the influence of leadership style on job satisfaction and service quality for nurses in hospitals. Search for articles accessed from an internet search 3 data base namely: EBSCHO, PubMed and Science Direct. Search used the keywords: Leadership style, Job Satisfaction, Quality Care, Nurse and Hospital.

\section{Inclusion and Exclusion Criteria}

The inclusion criteria of this study are articles published in the last 10 years (2010-2019), English, full text, open access, and research locations in hospitals. Exclusion criteria are abstract articles, articles that do not use English and articles that are not full text. Articles that fulfill the inclusion criteria are systematically collected and inspected. From the results of screening of titles and abstracts based on inclusion criteria, 15 articles were found to be synthesized to obtain conclusions. 


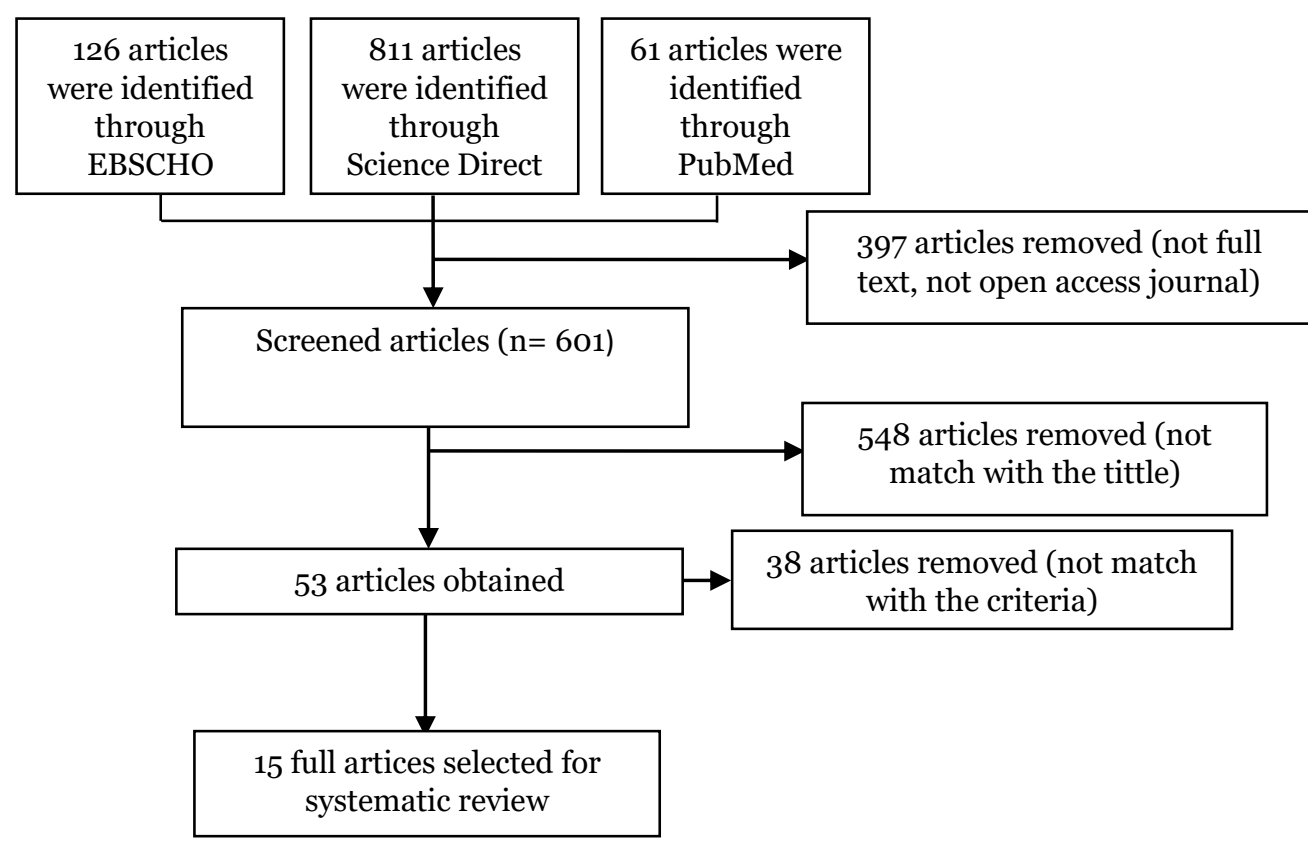

Figure 1. PRISMA Flow Diagram

\section{RESULTS}

Based on the results of the search, 53 articles that were appropriate to the purpose of the study were put together and screened whether the titles in the article were the same or not. After screening, there were 28 articles with the same title. From this article, screening was based on eligibility according to the inclusion criteria and exclusion obtained 15 articles for further review. Stages in the search for articles to get 15 articles that would be reviewed are illustrated in Figure 1.

Research obtained from several studies conducted in various countries including KSA, Ghana, China, Portugal, Malaysia, Ethiopia, Taiwan, Jordan, the Czech Republic, Canada, Italy, Greece and Indonesia. After an assessment of the study quality, 15 articles can be categorized well and data extraction was carried out. This data extraction was done by analyzing data based on the author's name, title, year, location, purpose, method, and research results by grouping important data in the article. The extraction results can be seen in Table 1 . 
Table 1. Results of article extraction

\begin{tabular}{|c|c|c|c|c|c|}
\hline No & Research Title & Author (Year) & Purpose of Research & $\begin{array}{c}\text { Research } \\
\text { Method }\end{array}$ & Results \\
\hline 1. & $\begin{array}{l}\text { Leadership and job } \\
\text { satisfaction among } \\
\text { Azorean hospital } \\
\text { nurses: an application } \\
\text { of the situational } \\
\text { leadership model }\end{array}$ & $\begin{array}{l}\text { Lui's Carlos et al. } \\
\text { (2011) }\end{array}$ & $\begin{array}{l}\text { Describe the nurse manager's } \\
\text { leadership behavior and } \\
\text { determine whether the } \\
\text { leadership component } \\
\text { influences job satisfaction } \\
\text { among nursing staff }\end{array}$ & $\begin{array}{l}\text { Quantitative } \\
\text { Descriptive } \\
\text { inferential and } \\
\text { correlational }\end{array}$ & $\begin{array}{l}\mathrm{p}=0.464, \text { Ho was rejected. There was a relationship } \\
\text { between leadership and job satisfaction among nurses } \\
\text { at Azorean hospitals. } \\
\text { Correlation }=0.169\end{array}$ \\
\hline 2 & $\begin{array}{l}\text { The impact of } \\
\text { leadership styles on } \\
\text { nurses satisfaction and } \\
\text { intention to stay } \\
\text { among Saudi nurses }\end{array}$ & $\begin{array}{l}\text { Abualrub and } \\
\text { Alghamdi } \\
\text { (2011) }\end{array}$ & $\begin{array}{l}\text { To examine the impact of the } \\
\text { nurse manager's leadership } \\
\text { style on Saudi nurse job } \\
\text { satisfaction and their intention } \\
\text { to stay in the workplace. }\end{array}$ & $\begin{array}{l}\text { Qualitative } \\
\text { Descriptive } \\
\text { correlational }\end{array}$ & $\begin{array}{l}\text { Nurses were more satisfied with leaders who showed } \\
\text { transformational leadership styles, and they were } \\
\text { satisfied with the work they choose to stay in the } \\
\text { workplace. } \\
\text { Pearson correlation between JS and TF: } r=0.45 \\
\text { Pearson correlation between JS and TA: } r=-0.14\end{array}$ \\
\hline 3 . & $\begin{array}{l}\text { Transformational } \\
\text { leadership: effect on } \\
\text { the job satisfaction of } \\
\text { Registered Nurses in a } \\
\text { hospital in China }\end{array}$ & $\begin{array}{l}\text { Wang et al. } \\
\text { (2012) }\end{array}$ & $\begin{array}{l}\text { Describe the relationship } \\
\text { between transformational } \\
\text { leadership in nurse managers } \\
\text { and job satisfaction among } \\
\text { nurses in tertiary care } \\
\text { hospitals in China }\end{array}$ & $\begin{array}{l}\text { Quantitative } \\
\text { Descriptive } \\
\text { correlational }\end{array}$ & $\begin{array}{l}\text { There was a statistically significant and positive } \\
\text { correlation between nurse manager transformational } \\
\text { leadership and job satisfaction }(\mathrm{r}=0.556, \mathrm{p}<0.001)\end{array}$ \\
\hline 4 & $\begin{array}{l}\text { The Influence of } \\
\text { Leadership Style on } \\
\text { Job Satisfaction among } \\
\text { Nurses. }\end{array}$ & $\begin{array}{l}\text { Ahmad et al. } \\
\text { (2013) }\end{array}$ & $\begin{array}{l}\text { To investigate } \\
\text { transformational and } \\
\text { transactional leadership styles } \\
\text { that can contribute to job } \\
\text { satisfaction among nurses }\end{array}$ & $\begin{array}{l}\text { Quantitative } \\
\text { Descriptive } \\
\text { correlational }\end{array}$ & $\begin{array}{l}\text { Correlation tests showed the strength and direction of } \\
\text { the relationship between leadership style and job } \\
\text { satisfaction. } \\
\text { Correlation between job satisfaction and } \\
\text { transformational style: } r=0.642, p<0.05 \\
\text { Correlation between job satisfaction and } \\
\text { transactional style: } r=0.392, p<0.05\end{array}$ \\
\hline 5 & $\begin{array}{l}\text { Relationship Between } \\
\text { Leadershipstyle of } \\
\text { Nurse Managers and } \\
\text { Nurses Job } \\
\text { Satisfaction in Jimma } \\
\text { University Specialized } \\
\text { Hospital. }\end{array}$ & $\begin{array}{l}\text { Negussie and } \\
\text { Asresash (2013) }\end{array}$ & $\begin{array}{l}\text { To investigate the relationship } \\
\text { between nurse manager } \\
\text { leadership style and nurse job } \\
\text { satisfaction at Jimma } \\
\text { University specialist hospitals }\end{array}$ & $\begin{array}{l}\text { Quantitative } \\
\text { Non } \\
\text { experimental } \\
\text { correlational } \\
\text { design }\end{array}$ & $\begin{array}{l}\text { Nurses prefer transformational leadership styles over } \\
\text { transactional leadership styles and have a moderate } \\
\text { level intrinsic }(\mathrm{M}=2.72, \mathrm{SD}=071) \text {. While } \\
\text { transactional leadership, was found to be statically } \\
\text { significant and correlated with extrinsic }(\mathrm{B}=0.45, \mathrm{p} \\
<\mathrm{O} 01) \text { and intrinsic job satisfaction }(\mathrm{B}=0.32, \mathrm{p}< \\
\text { 0.05) }\end{array}$ \\
\hline 6. & Effect of Leadership & Alshahrani and & To evaluate the effects of & Quantitative & Working under the leadership with a \\
\hline
\end{tabular}

The $6^{\text {th }}$ International Conference on Public Health Best Western Premier Hotel, Solo, Indonesia, October 23-24, 2019 | 464 https://doi.org/10.26911/the6thicph-FP.04.32 
Styles on Job

Satisfaction Among

Critical Care Nurses in

Aseer, Saudi Arabia.

7 The influences of

nursing

transformational

leadership style on the

quality of nurse'

working lives in

Taiwan: a cross-

sectional quantitative

study.

8 Leadership styles in nursing management: implications for staff outcomes.

$9 \quad$ Impact of leadership styles adopted by head nurses on job

satisfaction: a comparative study between governmental and private hospitals

in Jordan.

10 Nurse Managers

Leadership Styles: A

Study from a Czech

Profit Oriented

Hospital

11 Characteristics of Head Bednářová and Nurses' Leadership Style and Its Impact on Patient Satisfaction.
Baig (2015) (2015)

Asamani et al. (2015)

Mbarak

et al.

(2015)

Bednářová and

Lenka (2015)

Lenka (2015) transformational and

transactional leadership styles

of head nurses on the job

satisfaction of nurse staff in

critical care units (CCU)

To understand the influence of transformational Nursing leadership styles on the quality of life of nurses working in Taiwan

Investigate the nurse manager's leadership style and how they affect the nurse staff's job satisfaction

To explore how the leadership style of nurse leaders influences job satisfaction among nurses.

To find out the dominant leadership style and determine the leadership style that influences the job satisfaction of the nurse staff higher.

Look for the difference between assessing leadership styles and find out whether these differences have some
Cross Sectiona
transformational style showed significantly (p <0.05) higher job satisfaction. The nurses were quite satisfied with their work.

Quantitative Cross Sectional with supervisor support $\mathrm{r}=0.735$, job satisfaction $\mathrm{r}=$ 0.475 and organizational commitment $\mathrm{r}=0.321$.

Transformational leadership has a direct influence on supervisor support $(\beta=0.74)$. Greater supervisor support was associated with greater job satisfaction $(\beta=0.37)$, related to greater organizational commitment $(\beta=0.5)$.

Quantitative

Cross Sectional

The nurse manager's leadership style explained 29\% of the variance in staff job satisfaction. $\mathrm{R}^{2}=0.29$, $\mathrm{p}<0.001$

Quantitative

The level of job satisfaction among Nursing staff is Descriptive and higher in public hospitals than in private hospitals. A Comparative positive relationship was found between the overall score for transformational leadership and job satisfaction $(\mathrm{r}=0.374)$. The overall transactional leadership score was positively correlated with job satisfaction $(\mathrm{r}=0.391)$.

Quantitative

From 19 Departments, transactional style was commonly used in 11 departments. And of the eight remaining Departments, the transformational style was dominant. Transactional style was more correlated with employee satisfaction ( $0.538 \mathrm{vs}$ 0.229).

Quantitative The correlation between intellectual stimulation Pilot Study assessed by the head nurse and overall patient satisfaction $(\mathrm{r}=0.67)$ was statistically significant at the $10 \%$ level. 


\section{Effect of}

transformational

leadership on job

satisfaction and

patient safety

outcomes.

13 How staff nurses perceive the impact of nurse managers'

leadership style in terms of job

satisfaction: a mixed method study.

14 Relationship Between Nurse Managers' Leadership Styles and Staff Nurses' Job

Satisfaction in a Greek NHS Hospital

15 The Relationship between

Transformational Leadership and Quality of Nursing Work Life in Hospital. impact on patient satisfaction

Boamah et al. To investigate the impact of (2017) nurse managers' transformational leadership and patient safety outcomes.

Morisiani et al. To describe the nurse staff's (2017) perceptions related to the leadership style adopted by their nurse managers.

Konstantinou and Prezerakos

(2018)

Suratno

(2018)

To examine the relationship between nurse manager

leadership style and nurse job satisfaction at NHS hospitals, Greece.

To determine the relationship between transformational behaviors on job satisfaction

Quantitative

Cross Sectional

Transformational leadership has a strong and significant positive direct effect $(\beta=0.77$; ) on structural empowerment and has a positive effect on job satisfaction $(\beta=0.86)$. Nurse job satisfaction reduced the occurrence of adverse events $(\beta=-0.63$; $\mathrm{p}<0.05$ ).

Mix Method

study

Questionnaire leadership and the quality of work life of nurses. and Focus

Group

Discussion

Quantitative

Cross Sectional

The transactional style of leadership was weakly correlated to the satisfaction of nurse staff (0.22). In contrast, nurse staff satisfaction showed the highest positive correlation (Spearman Rho $=0.71$ ) with the IIA style, which was one of the transformational leadership styles.

Nurses prefer transformational leadership styles. In the bivariate analysis found a significant relationship - at the level of $0.20(p<0.20)$, between overall satisfaction, intrinsic satisfaction and extrinsic satisfaction scores and all subscales of MLQ 5X.

Quantitative Cross Sectional

The results showed that the highest value that was significant in the leadership style variable was Transformational leadership was significantly related to QNWL ( $\mathrm{p}=0000, \mathrm{r}=0.28)$. inspirational motivation which was 11.9 $(\mathrm{SD} \pm 3.33)$. 


\section{DISCUSSIONS}

Effective leadership in health services has been extensively researched over the past decade. Based on the analysis of the article, it was found that leadership style can influence job satisfaction in nurses in hospitals.

Carlo et al. (2011) found that there was a relationship between leadership and job satisfaction among nurses at Azorean hospital, Portugal with a correlation $r$ of o.169. This study was in line with study done by Avoka (2015) in Ghana which stated that nurse manager use different leadership styles depending on the situation, but are more likely to support leadership styles, followed by leadership styles that are oriented towards achieving and participatory leadership styles. The nurse manager's leadership style explained $29 \%$ of the variance in staff job satisfaction. $\mathrm{R} 2=0.29, \mathrm{p}<0.001$. Research of Wang et al in China also stated that there is a statistically significant positive correlation between nurse manager transformational leadership and job satisfaction $(\mathrm{r}=0.556, \mathrm{p}<0.001)$

A study done by Abualrub et al. (2011) stated that nurses were more satisfied with leaders who use transformational leadership styles and have the intention for nurses to keep working. Bass's Transformational Leadership Theory (1985) in Ismail et al. (2011) stated that in carrying out organizational functions, mutual understanding between leaders and subordinates can inspire their subordinates to support the interests of the organization by putting aside their personal interests. Transformational leaders refer to someone who was trying to show the organization new routes for improvement and progress by generating new ideas and perspectives (Jandaghi et al., 2009).
In the study of Negussie and Demissie (2013) in Ethiopia, it was found that nurses preferred and were more satisfied with the transformational leadership style rather than transactional, therefore, nurses' managers were expected to use the transformational leadership style to increase nurse job satisfaction. This was in line with research by Musaed et al. (2015) at KSA which found that working under the leadership with a transformational style showed significantly higher job satisfaction compared to the transactional style.

According to Maulizar et al. (2012), transformational leaders were basically leaders who have the ability to direct their subordinates to adapt to the environment to achieve success in the future. The basic principle of transformational leadership was the development of subordinates. In the research of Pin Yi Lin et al. (2015) in Taiwan found that transformational leadership style has a strong correlation with supervisor support $r=0.735$, job satisfaction $\mathrm{r}=0.475$ and organizational commitment $\mathrm{r}=$ o.321. Transformational leadership style has a direct influence on supervisor support $(\beta=0.74)$. Greater supervisor support was associated with greater job satisfaction $(\beta=$ 0.37 ), which in turn is positively related to greater organizational commitment $(\beta=$ 0.5).

In addition, leadership style also influenced the quality of service. Several studies have emphasized the importance of leadership styles for the quality of health services in hospitals (Sfantou et al., 2017). Research by Bednářová and Komárková (2015) in the Czech Republic found a correlation between intellectual stimulation of the head nurse and overall patient satisfaction $(\mathrm{r}=0.67)$. If nurses supported active problem solving, providing solutions

The $6^{\text {th }}$ International Conference on Public Health Best Western Premier Hotel, Solo, Indonesia, October 23-24, 2019| 467 https://doi.org/10.26911/the6thicph-FP.04.32 
and being creative would influence their work performance and then patients find that their care was more satisfying.

In the study of Sheila A. Boamah et al. (2017) in Ontario Canada, it was found that transformational leadership had strong and significant direct positive effects ( $\beta=0.77$; $p$ $<0.001$ ) on structural empowerment which in turn had a positive effect on job satisfaction $(\beta=0.86 ; p<0.001)$. Furthermore, nurse job satisfaction reduces the occurrence of adverse events ( $\beta=0.63 ; p<0.05)$. Whereas in the study of Suratno et al. (2018), it stated that transformational leadership was significantly related to the quality of work life of nurses $(p=0000, r=0.28)$. With the improved quality of work of nurses, in turn, would improve the nurses' quality of work of.

Leadership style has a significant influence on job satisfaction and service quality in nurses in hospitals. The transformational leadership style contributed more than the transactional leadership style. Transformational leadership style can provide increased patient satisfaction, provide a decrease in the number of undesirable events and increase $28 \%$ in the quality of work life of nurses, which in turn would improve the quality of services to nurses in the hospital.

On the other hand, transformational leadership can improve organizational commitment and performance so that it can be recommended that transformational leadership is a model that can be implemented in an organization based on a willingness to progress and can be maintained by using a flexibility approach and also in building job satisfaction, leadership was more concerned with internal and external appreciation for the employee.
REFERENCES

Abd Rahman Ahmad, Mohd Nazir, Mohd Adi, Haris Md Noor, Abdul Ghafar Abdul Rahman, Tan Yushuang (2013). The Influence of Leadership Style on Job Satisfaction among Nurses. Asian Social Science; 9: 9.

Abdelhafiz IM, Alloubani AM, Almatari M (2016): Impact of leadership style adopted by head nurses on job satisfaction: a comparative study between governmental and private hospitals in Jordan. Journal of Nursing Management. Yordania, 384-392.

Abualrub RF, Alghamdi MG (2011): The impact of leadership style on nurses' satisfaction and intentio to stay among Saudi nurses. Journal of NursingManagement.SaudiArabia.pp.1-11. Al-Sawai, A. Leadership of Healthcare Professionals: Where Do We stand? Oman Med. J. 2013, 28: 285-287

Alshahrani FM, Baig LA (2015): Effect of leadership style on job satisfaction among critical care nurses in Aseer, Saudi Arabia. Journal of the College of physicians and Surgeons Pakistan, 26(5): 366-370.

Bowles A, Bowles NB (2000). Comparative Study of Transformational Leadership in Nursing Development Units and Conventional Clinical Settings. Journal of Nursing Management 8: 69-76.

Christina Konstatinou, Panagiotis Prezerakos (2018). Relationship between Nurse Managers' Leadership Styles and Staff Nurses' Job Satisfaction in a Greek NHS Hospital. Yunani. American Journal of Nursing Science; 7(3): 45-50.

David, Fred R (2011): Strategic Management. Buku 1. Edisi 12 Jakarta. 
Gibson JL, Donnelly JH (2002). Organisasi Perilaku, Struktur dan proses (Organizational Behavior, Structure and Process). Jilid 1, Jakarta: Erlangga

Giuliana Morsiani, Annamaria Bagnasco, Loredana Sasso (2017). How staff nurses perceive the impact of nurse managers' leadership style in terms of job satisfaction: a mixed method study. Genoa, Italy. Journal of Nursing Management, 25: 119-128.

James Avoka Asamani, Florence Naab, Adelaide Maria Ansah Ofei (2016). Leadership styles in nursing management: implications for staff outcomes. Journal of Health Sciences, 6(1): 2336. http://www.jhsci.ba

Jandaghi G, Matin HZ, Farjami A (2009). Comparing Transformational Leadership in Successful and Unsuccessful Companies. The Journal of International Social Research. 357-372.

Kaluku Suratno, Saleh Ariyanti, Kadar Kusrini (2018). The Relationship between Transformational Leadership and Quality of Nursing Work Life in Hospital. Indonesia. International Journal of Caring Sciences, 11(3): 1416.

Kouzes JM, Posner BZ (2002). The Leadership Challenge, 3rd ed.; Jossey-Bass: San Francisco, CA, USA.

Lang TA, Hodge M, Olson V, Romano PS, Kravitz RL (2004). Nurse-patient ratios: A systematic review on the effects of nurse staffing on patient, nurse employee and hospital. J. Nurs. Adm., 34(04): 326-337.

Liu K, You LM, Chen SX, Hao YT, Zhu XW, Zhang LF, Aiken LH (2012). The relationship between hospital work environment and nurse outcomes in Guangdong, China: a nurse question- naire survey. NIH Public Access. J Clin Nurs, 1-17.

Luís Carlos Do Rego Furtado, Maria Da Graca, Francisco Jose (2011). Leadership and job satisfaction among Azorean hospital nurses: an application of the situational leadership model. Journal of Nursing Management, 19: 1047-1057.

Martina Bednářová, Lenka Komárková (2015). Characteristics of Head Nurses' Leadership Style and Its Impact on Patient Satisfaction. Journal University of Economics, Prague, Czech Republic.

Martina Bednářová, Lenka Komárková (2015). Nurse Managers Leadership Styles: A Study from a Czech Profit Oriented Hospital. Journal University of Economics, Prague, Czech Republic.

Maulizar, Musnadi S, Yunus (2012). Pengaruh Kepemimpina Transaksional Dan Transformasional Terhadap Kinerja Karyawan Bank Syariah Mandiri Cabang Banda (Effect of Transactional and Transformational Leadership on the Performance of Employees of Bank Syariah Mandiri Banda Branch). Jurnal Manajemen Pascasarjana Universitas Syiah Kuala. 1(1): 58-65.

Ministry of Health Republic of Indonesia (2017). Situasi Tenaga Keperawatan Indonesia (The Situation of Indonesian Nursing Personnels).

Negussie N, Demissie A (2013). Relationship between leadership style of nurses' managers and nurses' job satisfaction in Jimma University Specilialized Hospital. Ethiopia J Health Sci. 1(23): 49-58.

Ping-Yi Lin, Sara MacLennan, Nigel Hunt and Tom Cox. 2015. The influences of nursing transformational leadership

The $6^{\text {th }}$ International Conference on Public Health Best Western Premier Hotel, Solo, Indonesia, October 23-24, 2019| 469 https://doi.org/10.26911/the6thicph-FP.04.32 
style on the quality of nurse' working lives in Taiwan: a cross-sectional quantitative study. BMC Nursing 14: 33.

Ramoo V, Abdullah KL, Piaw CY (2013). The relationship between job satisfaction and intention to leave current employment among registered nurses in a teaching hospital in Malaysia. Journal of Clinical Nursing. Kuala Lumpur. 1-10.

Setyawati L (2010). 'Kesehatan dan Keselamatan Kerja di Rumah Sakit', disampaikan dalam Seminar Nasional $\mathrm{K}_{3}$ yang diselenggarakan oleh Universitas Respati 12 Juni 2010, Yogyakarta ('Occupational Health and Safety at the Hospital', delivered at the National Occupational Health and Safety Seminar held by Respati University in June 12, 2010, Yogyakarta).

Sfantou DF, Laliotis A, Patelarou AE, Sifaki- Pistolla D, Matalliotakis M, Patelarou E (2017). Importance of Leadership Style towards Quality of Care Measures in Healthcare Settings:

A Systematic Review. Healthcare, 5(4): 73 .

Sheila AB, Heather KS, Carol Wong and sean Clarke (2018). Effect of transformational leadership on job satisfaction and patient safety outcomes. Ontario, Canada. Elsevier Journal, Nursing Outlook 66: 180-189.
Undang-Undang Republik Indonesia Nomor 44 Tahun 2009 Tentang Rumah Sakit (Law of the Republic of Indonesia Number 44 of 2009 concerning Hospitals).

Wong CA, Cummings GG (2007). The relationship between nursing leadership and patient outcomes: A systematic review. J. Nurs. Manag. 15: 508-521.

Wuryanto E (2010). Hubungan antara kualitas kepemimpinan dengan kepuasan kerja perawat di Rumah Sakit Umum Daerah Tugurejo Semarang (The relationship between leadership quality and nurse job satisfaction at the Tugurejo Regional General Hospital, Semarang). Jurnal Keperawatan. 3(2): 7881.

Xiaohui Wang, Ratanawadee Chontawan \& Raymoul Nansupawat. 2011. Transformational leadership: effect on the job satisfaction of Registered Nurses in a hospital in China. Journal of Advanced Nursin, 444-451.

Yanidrawati K, Susilaningsih S, Somantri I (2012). Hubungan kepuasan kerja dengan kinerja perawat di ruang rawat inap rumah sakit umum daerah kabupaten bekasi (The relationship of job satisfaction with the performance of nurses in the inpatient room of Bekasi District Hospital). Fakultas Ilmu Keperawatan Universitas Padjajaran. 